\title{
Transfer of fatty acids from mothers to their calves during lactation in white whales Delphinapterus leucas
}

\author{
Annette Birkeland ${ }^{1,3}$, Kit M. Kovacs ${ }^{2}$, Christian Lydersen ${ }^{2}$, Otto Grahl-Nielsen ${ }^{1, *}$ \\ ${ }^{1}$ Department of Chemistry, University of Bergen, 5007 Bergen, Norway \\ ${ }^{2}$ Norwegian Polar Institute, 9296 Tromsø, Norway \\ ${ }^{3}$ Present address: Hydro Oleochemical, 3202 Sandefjord, Norway
}

\begin{abstract}
Blubber biopsies, through the entire blubber layer, were collected from the members of 4 mother-calf pairs of white whales Delphinapterus leucas from Storfjorden, Svalbard, Norway. In addition, milk samples were collected from all 4 adult females. The calves ranged in age/size from newborn (with the umbilical cord still attached; $140 \mathrm{~cm}$ in length) up to a $1 \mathrm{yr}$ old (body length of $255 \mathrm{~cm}$ ). Since white whale calves consume only milk during their first year of life, free-living mother-calf pairs provide an interesting opportunity to study the deposition of lipids (calf blubber) when the diet (i.e. milk) is known precisely. The blubber of the newborn calves had fatty-acid (FA) compositions that differed significantly from the FA compositions of both the milk and the blubber of their respective mothers. The FA composition of the blubber of calves changed gradually with age, coming to resemble the FA composition of the blubber of their mothers more closely, rather than shifting towards the FA composition of the milk, i.e. their diet. The largest calf in the study had a blubber FA composition similar to that of the adult whales. Analyses also showed that the FA composition of the milk was significantly different from the FA composition of the maternal blubber.
\end{abstract}

KEY WORDS: White whales · Fatty-acid composition $\cdot$ Lactation $\cdot$ Blubber $\cdot$ Milk

\section{INTRODUCTION}

The quantity of blubber in a given marine mammal varies on a seasonal basis in most species due to dramatic variations in levels of food intake that are correlated at least in part with cycles in life-history events such as breeding, lactation and moulting. During periods of the year when a positive energy balance is achieved, lipids are deposited in the blubber. Some studies suggest that the deposition of the dietary lipids into the blubber layer is achieved in a very conservative manner, more or less without alteration, and consequently that the fatty-acid (FA) composition of the blubber of marine mammals can be used to identify the diet from both a qualitatively and quantitatively perspective (e.g. Iverson et al. 1997, 2004, Hooker et al. 2001, Bradshaw et al. 2003). However, to date there is little direct evidence for the validity of this method for determining diet compositions (Grahl-Nielsen et al. 2004). It has been demonstrated in the laboratory that a dramatic shift in the diet of juvenile harp seals Phoca groenlandica from a single species of fish to another can be detected in the FA composition of the seals' blubber (Kirsch et al. 2000), but this experiment does little to simulate the natural complexity in marine mammal diets and their change through time in the wild.

Nursing mother-offspring pairs offer a special situation to study the influence of the diet on the composition of the blubber layer of marine mammals. For most species, milk comprises the offspring's total diet, so by analysing the milk FA composition and offspring's blubber FA composition, the question of how closely diet is reflected in the blubber of marine mammals may be addressed. In a study conducted on nurs- 
ing hooded seals Cystophora cristata, it was found that the blubber of pups attained an FA composition almost identical to that of the milk (Iverson et al. 1995a). However, in a study conducted on nursing grey seals Halichoerus grypus, it was found that the blubber of pups had a closer resemblance to the mother's blubber than to the milk (Grahl-Nielsen et al. 2000). In another study, the relative amounts of FAs in the blubber of nursing grey seal pups were found to be between one-third and one and a half times that of the relative amounts of the FA in the milk (Iverson et al. 2004). However, of the 67 FAs analysed, 42 differed by less than $10 \%$ between pup's blubber and milk. These conflicting results call for further studies of FA deposition during lactation.

White whales Delpinapterus leucas are mediumsized odontocetes that have a circumpolar Arctic distribution (Brodie 1989). Body sizes vary geographically in this species, ranging from lengths of 3.5 to $5.5 \mathrm{~m}$. Adult males are generally about $25 \%$ longer than females in any given area (O'Corry-Crowe 2002). Female white whales become sexually mature at 4 to $7 \mathrm{yr}$ of age and give birth to a single calf on average every third year thereafter (Brodie 1989). White whales are highly adapted to life in cold and icy waters; they possess a blubber layer that can be up to $15 \mathrm{~cm}$ thick (O'CorryCrowe 2002) and constitutes up to $40 \%$ of their total body mass (Sergeant \& Brodie 1969). They lack a dorsal fin, but they do have a dorsal ridge that they can use to break through thin ice. The epidermis of white whales, often referred to as the cork layer, is generally over $1 \mathrm{~cm}$ thick (Doidge 1990, St. Aubin et al. 1990), and in newborn calves this layer is over $2 \mathrm{~cm}$ thick (Doidge 1990). In calves, this layer is thought to act as a thermal buffer until sufficient blubber is deposited (Doidge 1990). Probably as a consequence of damaging epidermal cells during contact with ice, white whales go through an annual moult, during which the outer parts of the epidermis are renewed (St. Aubin et al. 1990). Calves are born in the summer after a gestation period of approximately 14.5 mo (Brodie 1971). They are about $1.6 \mathrm{~m}$ long at birth (O'Corry-Crowe 2002). During their first year, calves consume only milk; during the second year of life, when tooth eruption begins, milk is supplemented with some relatively easily captured prey (Brodie 1989).

The purpose of the present study was to investigate the FA composition of the blubber of white whale calves in relation to the FA composition of their dietwhich, at least during their first year of life, is exclusively the milk provided by their mothers. In addition, we wanted to compare the FA composition of the calves blubber with that of their mothers, and also to compare the FA composition of the milk with that of the maternal blubber.

\section{MATERIALS AND METHODS}

The field collections for this study took place in the northern parts of Storfjorden $\left(78^{\circ} 29^{\prime} \mathrm{N}, 19^{\circ} 22^{\prime} \mathrm{E}\right)$, Svalbard, Norway, during August 1998 and 1999. The white whales were slowly herded into a net set from the beach as described in Lydersen et al. (2001). Four mother-calf pairs were captured during the 2 field seasons (Table 1). When the whales were disentangled from the net and restrained in shallow water, the standard length (i.e. the straight-line distance along the dorsal side of the animal from the anterior tip of the head to the notch of the tail fluke) was measured to the nearest $0.05 \mathrm{~m}$. The calves' ages were estimated based on body lengths according to data from white whales from west Greenland (Heide-Jørgensen \& Teilmann 1994). The 2 smallest calves still had their umbilical cord attached and were within the size range reported for newborns; both calves were thought to be less than 1 wk old. Blubber samples through the entire blubber layer were collected from an area about $0.1 \mathrm{~m}$ in front of the dorsal ridge using custom-made, hollow, stainless-steel rods as described in Dahl et al. (2000). Each blubber sample was gently stretched out, wrapped in aluminium foil and kept frozen until analysis. Milk samples (10 to $50 \mathrm{ml}$ ) were collected $10 \mathrm{~min}$ postinjection of 20 IU oxytocin (Løvens Kemiske Fabrik, $10 \mathrm{IU} \mathrm{ml}^{-1}$ ) into the mammary glands and kept frozen $\left(-24^{\circ} \mathrm{C}\right)$ in plastic cryo-vials, which were wrapped in aluminium foil, until analyses (3 mo later). The Norwegian Animal Research Authority and the Governor of Svalbard approved all animal-handling procedures.

Subsamples of about $10 \mathrm{mg}$ each were cut from the blubber biopsies while they were still frozen, about 3 mo after collection. The cork was easily distinguished from the blubber. Two parallel subsamples were taken from the innermost part of the blubber. Single samples were also taken from the blubber cores outwards towards the cork layer, but due to variable condition of the cores, only 2 to 4 subsamples were obtained. Subsamples of similar size were taken from the inner, middle and outer part of the cork layer.

Table 1. Delphinapterus leucas. Standard length (SL) of mothers and calves of white whales live-captured in Storfjorden, Svalbard, August 1998 and 1999. Both calves, estimated to be less than $1 \mathrm{wk}$ old, still had their umbilical cord attached

\begin{tabular}{|lccc|}
\hline & $\begin{array}{c}\text { Mother } \\
\text { SL }\end{array}$ & $\begin{array}{c}\text { Calf } \\
\text { SL }\end{array}$ & $\begin{array}{c}\text { Estimated } \\
\text { calf age }\end{array}$ \\
\hline Pair A & 3.45 & 1.40 & $<1 \mathrm{wk}$ \\
Pair B & 4.15 & 1.45 & $<1 \mathrm{wk}$ \\
Pair C & 3.45 & 2.05 & $2 \mathrm{mo}$ \\
Pair D & 3.80 & 2.55 & $1 \mathrm{yr}$ \\
\hline
\end{tabular}


All blubber subsamples were transferred into thickwalled glass tubes with Teflon-lined screw caps. Five parallel samples of milk from each adult whale, each about 10 to $15 \mathrm{mg}$, were transferred to similar glass tubes. The milk samples were dried using a stream of nitrogen gas.

The samples were methanolysed/extracted in a 1step procedure (Grahl-Nielsen \& Barnung 1985) by treatment with $0.5 \mathrm{ml}$ anhydrous methanol $(\mathrm{MeOH})$, containing hydrogen chloride $(\mathrm{HCl})$ with a concentration of $2 \mathrm{~mol} \mathrm{l}^{-1}$ for $2 \mathrm{~h}$ in an oven at $90^{\circ} \mathrm{C}$. After cooling to room temperature, half the methanol was evaporated using nitrogen gas, and $0.5 \mathrm{ml}$ distilled water was added. The resulting FA methyl esters (FAME) were extracted from the methanol-water phase with $2 \times$ $1.0 \mathrm{ml}$ hexane. The concentration of the FAME in the combined extracts was adjusted by addition of hexane to obtain levels suitable for gas chromatography.

One $\mathrm{ml}$ of each of the final solutions was injected splitless (the split was opened after $4 \mathrm{~min}$ ) into a Hewlett-Packard 5890A gas chromatograph equipped with a Hewlett-Packard 7673A autosampler and a flame-ionisation detector. The column was $25 \mathrm{~m} \times$ $0.25 \mathrm{~mm}$ fused silica coated with polyethylene-glycol (CP-WAX 52CB Chrompack) of $0.2 \mathrm{~mm}$ thickness; helium was used as the mobile phase at 20 psi (1.4 bar). The injector and detector temperatures were 260 and $330^{\circ} \mathrm{C}$, respectively. After injection, the temperature of the oven was kept at $90^{\circ} \mathrm{C}$ for $4 \mathrm{~min}$ and then increased from 90 to $165^{\circ} \mathrm{C}$ at a rate of $30^{\circ} \mathrm{C} \mathrm{min}{ }^{-1}$ followed by a second phase of increase at $3^{\circ} \mathrm{C} \mathrm{min}^{-1}$ to $225^{\circ} \mathrm{C}$. This temperature was maintained for $10.5 \mathrm{~min}$. Samples were analysed in non-systematic order with a standard solution (GLC68D from Nu-Chek-Prep, containing 20 FAME) and pure hexane between every eighth sample. The detector output was coupled to a VG Multichrome laboratory data system for storage and treatment of the data.

The 33 most-prominent and well-defined peaks in the chromatograms were selected and identified by their retention times in comparison with the standard mixture and with gas-chromatography analyses of other samples supported by mass-spectrometry evaluations. The FAs are named according to the shorthand notation-(carbon chain length):(number of double bonds) $\mathrm{n} X$, where $\mathrm{n} X$ designates the position of the double bond nearest to the terminal methyl group. In the 11 FAs with 2 or more double bonds, there are 2 single bonds between each pair of double bonds.

Empirical response factors, relative to 18:0, were calculated for the 20 FAMEs present in known amounts in the standard mixture. The average of 10 runs of the standard mixture was used for these calculations. The response factors for each of the 13 FAMEs for which we had no standards were estimated by comparison with the standard FAME that resembled each most closely with respect to chain length and number of double bonds.

The peak areas were adjusted for, according to the response factors, and then the data were normalized for each sample by determination of the percentage of the sum for each FA. These data were logarithmically transformed to level out the large numerical differences between the amounts of each FA. The logtransformed data were subjected to principal component analysis (PCA), using the software package SIRIUS 6.5 (Kvalheim \& Karstang 1987).

\section{RESULTS}

A total of 33 FAs were identified in the various blubber and milk samples. Individual FA ranged from about $40 \%$ of the total composition $(16: 1 \mathrm{n} 7)$ to $0.04 \%$ (20:0) (Table 2). FAs with a lower abundance than $0.04 \%$ were not considered because of low precision in their determination. The FA compositions of the maternal blubber were quite similar among the individuals, whereas the FA compositions of the 4 calves differed markedly. Hence, the data for the adults are presented as mean values \pm standard deviation of the 4 individuals, while each calf is presented separately in Table 2. For the inner layer the mean of the 2 parallel subsamples from each animal was used. Additionally, no systematic differences were apparent among the 4 blubber samples taken at increasing distances from the inner layer or among the 3 cork samples. Therefore, the values for the outer blubber samples were pooled for each animal, as were the values for the cork samples.

For the adult white whales, the cork layer was different from the outer blubber layer with respect to the relative amounts of 21 of the FAs ( $p<0.05$, Student's $t$-test) (Table 2). The general trend was that FAs with 14 and 16 carbons, except 16:0, occurred in lower abundance in the cork layer, while the longer-chain FAs, except 18:3n3, 18:4n4 and 20:1n9, occurred in higher amounts in the cork compared to the outer blubber.

The differences between the amounts of the various FAs between the outer and inner blubber layers in adults were much less pronounced. Only 5 of the FAs were significantly different in terms of their relative proportions between these 2 blubber layers $(p<0.05$, $t$-test). These were 14:1n5 and iso-15:0, with higher relative amounts in the outer blubber layer, and 20:1n9, 22:1n9 and 22:1n11, with higher values in the inner layer.

The FA composition of the milk was quite different from that of the inner blubber layer of the adult females, with significant differences in the amounts of 
Table 2. Delphinapterus leucas. Average amounts of fatty acids (FAs), as percentage of sum \pm SD, in white whale milk, and in the cork layer and inner and outer blubber layer of white whale mothers $(\mathrm{N}=4)$ and calves (a: youngest calf, b: next youngest, etc.). Inequality symbols are given for the FAs where there are significant differences ( $\mathrm{p}<0.05, t$-test) between the cork layer and the outer blubber layers, the outer and inner blubber layers, and the inner blubber layer and the milk, respectively. SFA: saturated fatty acids; MUA: monounsaturated fatty acids; PUFA: polyunsaturated fatty acid

\begin{tabular}{|c|c|c|c|c|c|c|c|c|c|c|c|c|c|c|c|c|c|c|c|}
\hline \multirow{3}{*}{$\begin{array}{l}\text { Fatty } \\
\text { acids }\end{array}$} & \multicolumn{7}{|c|}{ Adults } & \multicolumn{12}{|c|}{ Calves } \\
\hline & \multirow{2}{*}{\multicolumn{2}{|c|}{$\begin{array}{l}\text { Cork } \\
\text { layer }\end{array}$}} & \multirow{2}{*}{\multicolumn{2}{|c|}{$\begin{array}{l}\text { Outer } \\
\text { blubber }\end{array}$}} & \multirow{2}{*}{\multicolumn{2}{|c|}{$\begin{array}{l}\text { Inner } \\
\text { blubber }\end{array}$}} & \multirow[t]{2}{*}{ Milk } & \multicolumn{4}{|c|}{ Inner blubber } & \multicolumn{4}{|c|}{ Outer blubber } & \multicolumn{4}{|c|}{ Cork layer } \\
\hline & & & & & & & & $\mathrm{a}$ & $\mathrm{b}$ & $\mathrm{C}$ & $\mathrm{d}$ & $\mathrm{a}$ & $\mathrm{b}$ & $\mathrm{C}$ & d & $\mathrm{a}$ & $\mathrm{b}$ & $\mathrm{C}$ & d \\
\hline 14:0 & $3.6 \pm 0.8$ & $<$ & $5.3 \pm 0.9$ & & $5.6 \pm 0.7$ & $>$ & $3.9 \pm 0.2$ & 10 & 5.9 & 5.1 & 4.6 & 11 & 6.7 & 5.2 & 5.0 & 3.5 & 4.2 & 3.0 & 4.3 \\
\hline $14: 1 \mathrm{n} 9$ & $0.4 \pm 0.3$ & & $1.0 \pm 0.6$ & & $0.8 \pm 0.4$ & $>$ & $0.14 \pm 0.09$ & 0.04 & 0.07 & 0.13 & 0.25 & 0.03 & 0.07 & 0.09 & 0.18 & 0.13 & 0.08 & 0.17 & 0.20 \\
\hline $14: 1 \mathrm{n} 7$ & $0.3 \pm 0.2$ & $<$ & $0.6 \pm 0.3$ & & $0.6 \pm 0.3$ & $>$ & $0.05 \pm 0.02$ & 0.33 & 0.26 & 0.14 & 0.21 & 0.28 & 0.41 & 0.13 & 0.22 & 0.18 & 0.23 & 0.17 & 0.22 \\
\hline $14: 1 \mathrm{n} 5$ & $1.5 \pm 0.3$ & $<$ & $2.1 \pm 0.3$ & $>$ & $1.5 \pm 0.3$ & $>$ & $0.12 \pm 0.04$ & 6.0 & 3.0 & 2.0 & 1.5 & 8.8 & 6.8 & 2.7 & 2.5 & 1.7 & 3.5 & 1.2 & 1.9 \\
\hline i-15:0 & $0.6 \pm 0.2$ & $<$ & $1.0 \pm 0.2$ & $>$ & $0.66 \pm 0.08$ & $>$ & $0.26 \pm 0.05$ & 1.4 & 1.4 & 1.2 & 0.81 & 5.8 & 4.1 & 1.9 & 1.6 & 1.2 & 2.1 & 0.63 & 1.0 \\
\hline $15: 0$ & $0.25 \pm 0.05$ & $<$ & $0.34 \pm 0.03$ & & $0.34 \pm 0.03$ & $>$ & $0.28 \pm 0.03$ & 0.21 & 0.25 & 0.28 & 0.31 & 0.31 & 0.29 & 0.30 & 0.35 & 0.31 & 0.25 & 0.22 & 0.29 \\
\hline $16: 0$ & $7.9 \pm 0.4$ & $>$ & $6.7 \pm 0.4$ & & $7.0 \pm 0.6$ & $<$ & $9.1 \pm 0.3$ & 11 & 7.5 & 7.2 & 7.6 & 10 & 7.4 & 7.6 & 7.2 & 15 & 10 & 9.2 & 7.5 \\
\hline 16:1n11 & $0.9 \pm 0.3$ & $<$ & $1.5 \pm 0.5$ & & $1.4 \pm 0.3$ & $>$ & $0.3 \pm 0.1$ & 0.14 & 0.33 & 0.59 & 0.78 & 0.08 & 0.22 & 0.55 & 0.77 & 0.29 & 0.22 & 0.46 & 0.76 \\
\hline 16:1n9 & $1.1 \pm 0.4$ & $<$ & $1.7 \pm 0.6$ & & $1.7 \pm 0.6$ & $>$ & $0.4 \pm 0.1$ & 0.57 & 0.55 & 0.72 & 0.89 & 0.40 & 0.57 & 0.67 & 0.97 & 1.1 & 0.77 & 0.57 & 0.90 \\
\hline $16: 1 \mathrm{n} 7$ & $17 \pm 1$ & $<$ & $23 \pm 1$ & & $20 \pm 3$ & $>$ & $13.9 \pm 0.8$ & 39 & 29 & 26 & 21 & 45 & 38 & 28 & 24 & 16 & 27 & 17 & 20 \\
\hline $16: 1 \mathrm{n} 5$ & $0.34 \pm 0.03$ & $<$ & $0.39 \pm 0.03$ & & $0.39 \pm 0.03$ & $>$ & $0.29 \pm 0.03$ & 0.21 & 0.22 & 0.27 & 0.31 & 0.15 & 0.22 & 0.25 & 0.33 & 0.29 & 0.36 & 0.29 & 0.31 \\
\hline $16: 2 \mathrm{n} 6$ & $0.44 \pm 0.09$ & $<$ & $0.7 \pm 0.1$ & & $0.66 \pm 0.09$ & & $0.65 \pm 0.08$ & 0.28 & 0.43 & 0.62 & 0.66 & 0.14 & 0.30 & 0.52 & 0.63 & 0.19 & 0.17 & 0.45 & 0.56 \\
\hline $18: 0$ & $3.3 \pm 0.8$ & $>$ & $0.9 \pm 0.1$ & & $0.93 \pm 0.06$ & $<$ & $2.6 \pm 0.6$ & 0.85 & 0.88 & 0.93 & 1.1 & 0.46 & 0.90 & 1.5 & 1.1 & 4.9 & 2.8 & 4.1 & 2.2 \\
\hline $18: 1 \mathrm{n} 9$ & $20 \pm 1$ & & $20 \pm 1$ & & $20 \pm 1$ & $>$ & $14 \pm 4$ & 11 & 16 & 17 & 17 & 6.8 & 12 & 16 & 17 & 23 & 19 & 18 & 17 \\
\hline $18: 1 \mathrm{n} 7$ & $4.8 \pm 0.7$ & $>$ & $3.2 \pm 0.3$ & & $3.1 \pm 0.3$ & & $3.2 \pm 0.6$ & 3.1 & 3.0 & 3.4 & 3.4 & 2.0 & 2.8 & 3.3 & 3.4 & 10 & 10 & 6.0 & 4.4 \\
\hline $18: 1 \mathrm{n} 5$ & $0.57 \pm 0.07$ & & $0.54 \pm 0.04$ & & $0.52 \pm 0.06$ & $<$ & $0.71 \pm 0.07$ & 0.44 & 0.50 & 0.52 & 0.63 & 0.20 & 0.43 & 0.54 & 0.58 & 0.45 & 0.61 & 0.58 & 0.66 \\
\hline $18: 2 \mathrm{n} 6$ & $1.20 \pm 0.04$ & & $1.22 \pm 0.06$ & & $1.27 \pm 0.02$ & $>$ & $0.8 \pm 0.2$ & 0.36 & 0.63 & 0.80 & 0.87 & 0.19 & 0.45 & 0.80 & 0.87 & 0.56 & 0.58 & 1.2 & 0.97 \\
\hline $18: 3 \mathrm{n} 3$ & $0.48 \pm 0.03$ & $<$ & $0.58 \pm 0.03$ & & $0.53 \pm 0.03$ & $>$ & $0.41 \pm 0.09$ & 0.16 & 0.28 & 0.39 & 0.47 & 0.09 & 0.18 & 0.36 & 0.46 & 0.21 & 0.17 & 0.46 & 0.44 \\
\hline 18:4n3 & $0.4 \pm 0.1$ & $<$ & $0.8 \pm 0.1$ & & $0.8 \pm 0.1$ & & $0.9 \pm 0.2$ & 0.27 & 0.38 & 0.66 & 0.89 & 0.10 & 0.21 & 0.52 & 0.73 & 0.15 & 0.12 & 0.24 & 0.61 \\
\hline $20: 0$ & $0.14 \pm 0.04$ & $>$ & $0.05 \pm 0.01$ & & $0.05 \pm 0.01$ & $<$ & $0.07 \pm 0.01$ & 0.04 & 0.04 & 0.04 & 0.05 & 0.04 & 0.08 & 0.07 & 0.07 & 0.21 & 0.18 & 0.16 & 0.09 \\
\hline 20:1n11 & $2.2 \pm 0.1$ & & $2.1 \pm 0.2$ & & $2.1 \pm 0.3$ & & $2.4 \pm 0.7$ & 0.65 & 2.2 & 1.5 & 1.6 & 0.25 & 1.3 & 1.4 & 1.6 & 0.42 & 0.84 & 1.9 & 1.8 \\
\hline 20:1n9 & $9 \pm 1$ & $<$ & $10.3 \pm 0.8$ & $<$ & $12 \pm 1$ & $<$ & $20 \pm 2$ & 3.5 & 12 & 11 & 11 & 1.2 & 6.4 & 9.5 & 10 & 1.2 & 3.5 & 7.7 & 9.6 \\
\hline $20: 1 \mathrm{n} 7$ & $0.5 \pm 0.1$ & $>$ & $0.25 \pm 0.04$ & & $0.29 \pm 0.08$ & $<$ & $0.49 \pm 0.04$ & 0.16 & 0.26 & 0.21 & 0.28 & 0.07 & 0.20 & 0.27 & 0.22 & 0.76 & 0.88 & 0.54 & 0.38 \\
\hline $20: 2 \mathrm{n} 6$ & $0.18 \pm 0.04$ & & $0.13 \pm 0.03$ & & $0.16 \pm 0.02$ & & $0.20 \pm 0.05$ & 0.22 & 0.14 & 0.10 & 0.18 & 0.06 & 0.12 & 0.15 & 0.18 & 0.71 & 0.10 & 0.25 & 0.19 \\
\hline $20: 4 \mathrm{n} 6$ & $1.1 \pm 0.3$ & $>$ & $0.3 \pm 0.1$ & & $0.28 \pm 0.08$ & & $0.30 \pm 0.04$ & 0.29 & 0.24 & 0.37 & 0.33 & 0.24 & 0.36 & 0.72 & 0.41 & 2.2 & 1.2 & 1.7 & 0.68 \\
\hline $20: 3 n 3$ & $0.12 \pm 0.08$ & & $0.06 \pm 0.01$ & & $0.06 \pm 0.02$ & & $0.06 \pm 0.01$ & 0.07 & 0.63 & 0.08 & 0.05 & 0.06 & 0.10 & 0.07 & 0.08 & 0.15 & 0.08 & 0.19 & 0.07 \\
\hline $20: 4 n 3$ & $1.1 \pm 0.2$ & $>$ & $0.6 \pm 0.2$ & & $0.6 \pm 0.2$ & $<$ & $0.7 \pm 0.1$ & 0.33 & 0.50 & 0.68 & 0.78 & 0.14 & 0.28 & 0.60 & 0.67 & 0.40 & 0.34 & 1.6 & 1.1 \\
\hline $20: 5 n 3$ & $5.1 \pm 0.8$ & & $4 \pm 1$ & & $4 \pm 1$ & $<$ & $6 \pm 2$ & 2.2 & 2.9 & 6.0 & 6.6 & 1.3 & 2.1 & 5.5 & 5.3 & 2.4 & 1.8 & 5.3 & 5.8 \\
\hline 22:1n11 & $2.4 \pm 0.4$ & & $2.7 \pm 0.3$ & $<$ & $3.8 \pm 0.8$ & $<$ & $6 \pm 2$ & 0.76 & 3.1 & 2.7 & 3.0 & 0.28 & 1.5 & 2.3 & 2.9 & 0.26 & 0.72 & 1.8 & 2.8 \\
\hline 22:1n9 & $1.1 \pm 0.2$ & $>$ & $0.47 \pm 0.08$ & $<$ & $0.6 \pm 0.1$ & $<$ & $0.9 \pm 0.2$ & 0.12 & 0.47 & 0.43 & 0.44 & 0.09 & 0.22 & 0.39 & 0.42 & 0.30 & 0.34 & 1.4 & 0.87 \\
\hline $22: 5 \mathrm{n} 3$ & $3.9 \pm 0.8$ & $>$ & $1.6 \pm 0.7$ & & $1.8 \pm 0.7$ & $<$ & $2.5 \pm 0.5$ & 2.61 & 2.6 & 2.9 & 3.2 & 1.6 & 1.8 & 2.5 & 2.5 & 5.4 & 2.9 & 4.8 & 3.6 \\
\hline $22: 6 n 3$ & $6.7 \pm 0.7$ & & $6 \pm 2$ & & $6 \pm 2$ & & $8 \pm 2$ & 3.6 & 5.0 & 6.2 & 9.6 & 1.9 & 3.6 & 5.7 & 7.4 & 5.3 & 4.4 & 6.8 & 7.9 \\
\hline 24:1n9 & $1.5 \pm 0.5$ & $>$ & $0.12 \pm 0.02$ & & $0.14 \pm 0.02$ & & $0.17 \pm 0.06$ & 0.15 & 0.12 & 0.14 & 0.08 & 0.12 & 0.21 & 0.23 & 0.14 & 1.5 & 0.92 & 1.9 & 0.91 \\
\hline$\Sigma \mathrm{SFA}$ & $16 \pm 1$ & & $14 \pm 1$ & & $14.6 \pm 0.8$ & & $16.2 \pm 0.8$ & 24 & 16 & 15 & 14 & 28 & 20 & 17 & 15 & 25 & 20 & 17 & 15 \\
\hline$\Sigma$ MUFA & $63 \pm 2$ & & $70 \pm 2$ & & $69 \pm 3$ & & $63 \pm 4$ & 66 & 71 & 66 & 62 & 66 & 71 & 66 & 66 & 57 & 68 & 60 & 63 \\
\hline$\Sigma$ PUFA & $21 \pm 1$ & & $16 \pm 2$ & & $16 \pm 2$ & & $20 \pm 2$ & 10 & 13 & 19 & 24 & 6 & 9 & 17 & 19 & 18 & 12 & 23 & 22 \\
\hline
\end{tabular}

20 of the FAs ( $p<0.05, t$-test) (Table 2$)$. The saturated FAs, those with 14 and 15 carbons, had lower values in the milk, while FAs with 16, 18 and 20 carbons had higher percentages in milk compared with the blubber. Among the monounsaturated FAs, those with 14, 16 and 18 carbons occurred in lower relative amounts in the milk than in the blubber, while the longer-chain monounsaturated FAs were present in higher relative amounts in the milk. The polyunsaturated FAs, 20:5n3, $22: 5 n 3$ and 22:6n3, were present in higher relative amounts in the milk than in the inner blubber layer.

The amounts of each FA in the inner blubber layer varied markedly and systematically with age between the 4 calves (Table 2). Generally speaking, the amounts of FAs with short chains (up to 16 carbons), decreased with age, while those with 18 or more carbons increased with age. However, while the long-chain polyunsaturated FAs occur in substantial amounts in Calf $a$, the youngest calf, and increase gradually with age through to the eldest calf (Calf d), the monounsaturated 20 and 22 carbon FA were only present in low amounts in Calf a and increased abruptly from Calf a to Calf $b$ and stayed at this level in Calves c and $\mathrm{d}$.

There were some differences between the inner and outer blubber layers of the calves, but the change in the amounts of the various FAs in relation to the age of the calves was parallel in the 2 layers (Table 2). There were 
clear differences between the relative amounts of the various FAs when comparing the inner blubber layer of the youngest calf with the milk (Table 2). The 1 yr old calf had a FA composition in the inner blubber layer that was similar to the FA composition in the inner blubber layer of the adult whales.

PCA showed a clear distinction between the FA composition of the cork and the blubber of the adult white whales (Fig. 1). Some degree of individual variation is also apparent. The position of the various FAs in the plot indicates their significance regarding distinction among the samples. The 11 FAs that were significantly different between the blubber and cork layers in Table 2 are found to the far right or far left in the plot (Fig. 1), while the FAs which are more similar in the groups are located closer to the origin in the plot.

The cork layer of the 2 youngest calves differed from the adult cork layer, while the cork layer of the 2 mo old and 1 yr old calves did not differ from that of their mothers (Fig. 2). The typical marine FAs, n9 and n11 (monoenes with 20 and 22 carbons), occurred in higher relative amounts in the adult whales cork layers, while

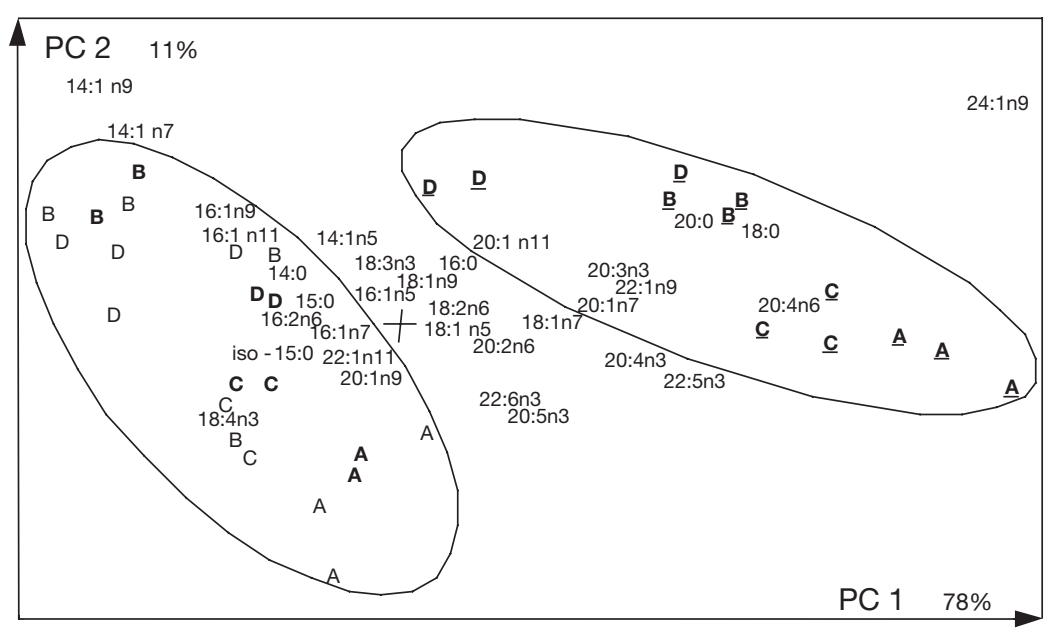

Fig. 1. Delphinapterus leucas. Biplot of the fatty-acid (FA) composition of white whale maternal blubber (bold letters: inner blubber layer; non-bold letters: outer blubber layer) to the left, and the maternal cork layer (underlined letters) to the right. Samples with the same letter belong to the same individual. The further away from the origin an FA is located in the plot, horizontally or vertically, the more important it is for the direction of the first and second principal components (PCs), respectively. A sample located close to an FA contains higher relative amounts of that FA than samples more remotely located the shorter-chain monoenes and saturated FAs occurred in higher relative amounts in the youngest calves (Fig. 2).

The small differences in FAs between the outer and inner blubber layers that were indicated in Table 2 become more evident when we exclude the cork layer from the analyses and carry out a new PCA based on the FA compo-sitions of the inner and outer blubber layers of only the adult whales (Fig. 3). The differences in FA composition between the individuals are, however, greater than the differences between the 2 layers. The individual differences are manifested along the first PC, which accounts for $64 \%$ of the total variance among the samples, while the difference between the layers is along the second $\mathrm{PC}$, which accounts for only $14 \%$ of the total variance (Fig. 3). For all 4 adults the 2 parallel samples from the inner layer are located in the upper region of the plot. The monoenic FAs, 20:1n9, 22:1n9 and 22:1n11, which were found to be significantly more abundant in the inner blubber layer (Table 1) are located in the upper part of the biplot, and 14:1n5 and iso15:0, which are significantly more abundant in the outer layer, are located in the lower part of the plot. The 4 monoenic FAs, with 14 and 16 carbons, occurring on the far left side of the biplot, and the 5 polyenic FAs, with 20 and 22 carbons, occurring on the far right side of the biplot, are the most different among the 4 adult whales, and lead to the spread among them in the plot (Fig. 3). 


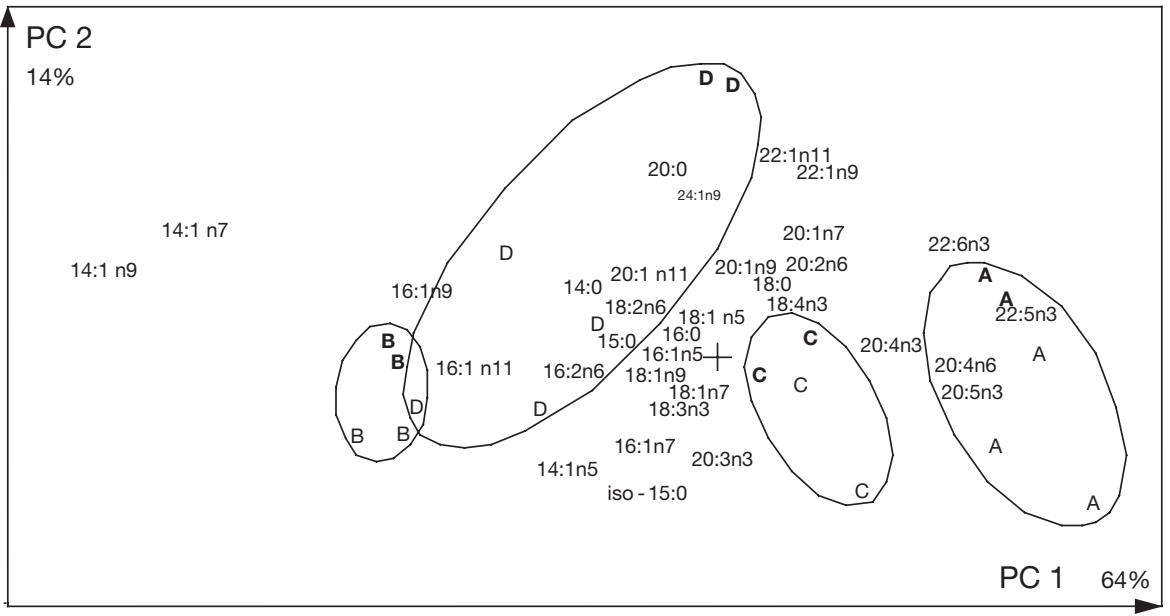

Fig. 3. Delphinapterus leucas. Biplot of the FA composition in blubber samples from 4 white whale mothers (bold letters: inner blubber layer; non-bold letters: outer blubber layer)

A PCA of the FA composition of the maternal blubber, calf blubber and milk shows clear differences between the various samples (Fig. 4). The largest differences (i.e. along the first $\mathrm{PC}$, accounting for $57 \%$ of the total variance) are between the milk samples on one side of the plot and all of the blubber samples on the other side. There is also a clear distinction among the various blubber samples depicted along the second PC (accounting for $11 \%$ of the total variance) (Fig. 4). The maternal blubber samples are grouped together in the upper part of the plot. The FA composition of the blubber of the youngest calf is very different from that of the adult blubber, and the FA composition of calf blubber appears to change gradually with age towards that of their mothers, not towards the milk, i.e. their diet. The 1 yr old calf has a blubber FA composition that is quite similar to that of the adult whales.

\section{DISCUSSION}

It has been known for quite some time that whales and walruses have FA gradients in their blubber (Ackman et al. 1965, 1975, West et al. 1979), and more recently this has also been shown for seals (Fredheim et al. 1995, Käkelä \& Hyvärinen 1996). The stratification is surprisingly similar in all species, cetaceans and pinnipeds alike, with higher relative amounts of the 14, 16 and 18 monoenic FAs in the outer layer and higher relative amounts of the 20 and 22 monoenic FAs, as well as the saturated and polyunsaturated FAs, in the inner layer (Olsen \& Grahl-Nielsen 2003).

This similarity among all marine mammals studied to date strongly suggests that the composition of the blubber is at least in part a consequence of its various functions rather than simply being a reflection of diet. The blubber is not merely an energy-storage site; it is a dynamic tissue that insulates the body and promotes swimming efficiency via flexibility and reduction of resistance in the water, as well as being involved in controlling buoyancy.

The cork layer of white whales represents an extra $\mathrm{cm}$ of tissue outside the skin and blubber layer. The outer part of this layer is replaced on an annual basis during a moult-like process that is unique to this species among cetaceans (St. Aubin et al. 1990). In this study, the cork layer of white whales was shown to have a FA composition which is significantly different from that of the blubber. It has larger relative amounts of the FAs with 20 and more carbons and also higher amounts of the saturated FAs 16:0 and 18:0, indicating that the cork layer is a different tissue, with different functions, to the blubber.

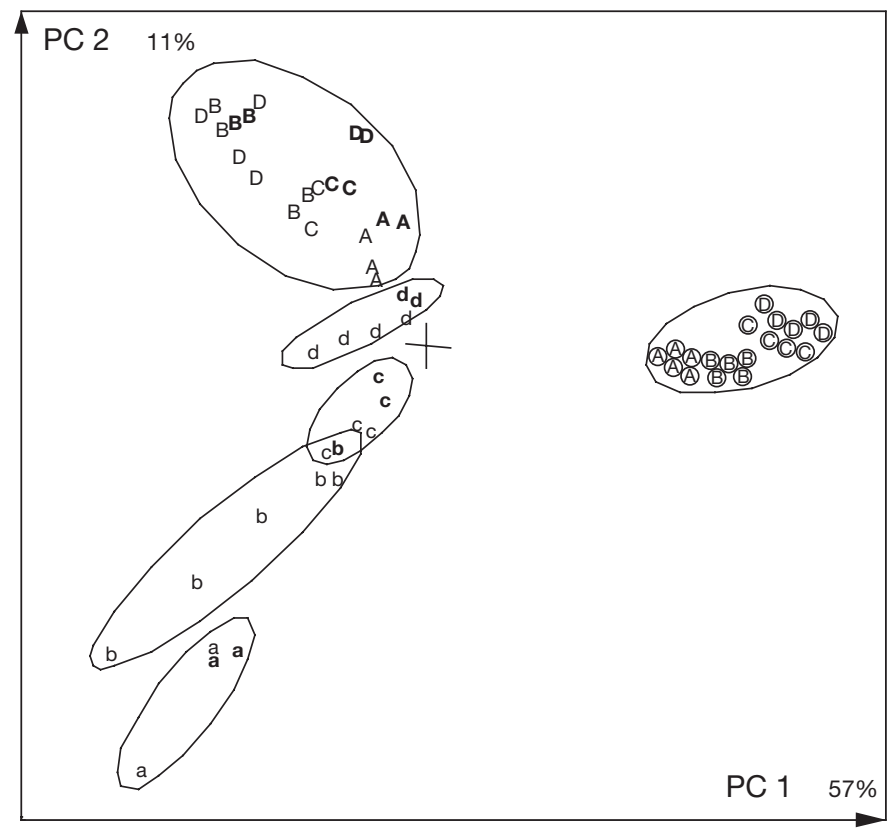

Fig. 4. Delphinapterus leucas. Biplot of the FA composition in blubber samples from white whale mothers (upper-case letters; bold: inner blubber layer, non-bold: outer blubber layer) and calves (lower-case letters; bold: inner blubber layer, non-bold: outer blubber layer) and of milk samples (encircled letters). Samples with same letter belong to the same pair: a is the youngest calf, $\mathrm{b}$ the second-youngest, etc. 
The unique composition of the cork layer of the newborn calves in this study supports Doidge's (1990) suggestion that the cork layer may have a different function during the first weeks. The composition of the cork layer changes more rapidly toward the adult composition than the calves' blubber composition changes toward the adult form.

In the layers beneath the cork layer, white whale blubber has a pattern of stratification in FA composition similar to the blubber of other cetaceans and of pinnipeds (Fredheim et al. 1995, Olsen \& Grahl-Nielsen 2003). However, the stratification seen in white whale blubber is less pronounced than that seen in the blubber of other whales, which may be due to a structural, shielding effect from the overlying cork layer.

During milk synthesis, milk FAs are derived from direct uptake of circulating lipids (Iverson 1993). The circulating lipids are mobilized from maternal blubber in animals that are fasting. However, if the lactating animal is foraging, as is the case for the white whales, dietary lipids will be the primary source of the circulating lipids (Iverson 1993). Thus, lipids from dietary intake will be channelled into the mammary gland. According to Iverson (1993) FA composition is conserved through the various transitions the lipids are undergoing, i.e. from diet to circulating lipids and further through milk synthesis, but the close similarity in the FA composition of the milk from the 4 whales in different stages of lactation (Fig. 4) indicates that the milk has a species-specific composition of FA that changes little during the first year of lactation.

The youngest white whale calves in this study had FA compositions in both the inner and outer blubber layers that were distinctly different from their mothers. This was similar to what has been found in newborn hooded seal pups (Iverson et al. 1995a), and the differences are quite similar for the 2 species, with higher amounts of the saturated FAs 14:0 and 16:0 and of the monounsaturated $14: 1 \mathrm{n} 5$ and $16: 1 \mathrm{n} 7$ in the offspring. In addition, the white whale calves had higher relative amounts of $18: 1 n 9$ in their blubber than the mothers, something that was not the case for the hooded seal. These features are likely the results of foetal synthesis of the saturated FAs, and an active $\Delta-9$ desaturase system. All mammals have enzymes that promote FA elongation and $\Delta$-9-desaturation; the activities of these enzymes are regulated following specific tissue needs (Kouba et al. 1999, Ntambi 1999). The low amount of 18:0, in relation to the much higher amount of 18:1n9, must be a result of a more rapid $\Delta-9$ desaturase system than the system(s) responsible for elongating 16:0 to 18:0.

FAs with 20 and 22 carbons are not readily synthesized in mammals (Iverson et al. 1995b). The low amounts of these FAs in the blubber of the shortest calf indicate that this animal was probably younger than the other calf still bearing an umbilical cord (closer to newborn) (see Iverson et al. 1995a). There was a difference between mono- and polyunsaturated FAs, in that the amounts of the monounsaturated FAs in Calf a were lower than the amounts of the polyunsaturated FAs, compared with the relative amounts of these groups in the adults. This was also found in the blubber of newborn hooded seals (Iverson et al. 1995a) and indicates that transfer of polyunsaturated FAs does take place at a greater rate between a mother and a foetus compared with the monounsaturated FAs.

The milk of the white whales contained relatively high amounts of monounsaturated FAs, and the amounts of monounsaturated FAs increased abruptly from Calf a to Calf $b$ and stayed at this level in Calves $\mathrm{c}$ and $\mathrm{d}$. They did not, however, reach the levels found in the milk. The clear difference between Calves a and b showed that Calf a had diverged the least from the newborn state. It appears that changes in the blubber FA composition might occur very rapidly during the first days after parturition, compared with during later stages of calf development.

Though the FA composition of the blubber of the youngest calves was very different from the FA composition of both the blubber of their mothers and of the milk, the 1 yr old calf had a blubber FA composition that was quite similar to that of the adult whales, but not similar to its diet, i.e. the milk. It thus appears that the blubber FA composition is not determined directly by the FA composition of the diet, but rather it is also influenced by other factors connected to the physiological and functional properties that blubber exhibits.

Iverson et al. (1995a) suggested that for hooded seal pups FAs were deposited directly into the blubber from the milk, without modification of their relative amounts (Iverson et al. 1995a). It was concluded that the diet FAs determined the composition of the pup blubber lipids. However, in the case of the hooded seals, the milk and the maternal blubber had quite similar FA compositions. Therefore, the change in the FA composition of the blubber of the newborn pup towards the composition of the milk is also a change towards the composition of the maternal blubber. Consequently, it cannot be concluded that it is the diet that determines the FA composition.

In the present investigation it has been possible to study the deposition of lipids in the blubber during growth of a marine mammal where the diet composition (milk composition) is precisely known. The FA composition of the blubber changed distinctly from a typical newborn state towards a composition that is typical for adults of the species. These changes during growth occur semi-autonomously of the diet. Of course, all nutrients come from the diet, but the relative composition of the FAs is altered during uptake. 
Even though lactating mother-offspring pairs represent an apparently good 'natural' model for studying the effects of dietary FAs on the FA composition in the depot fat, we have to bear in mind that this period is unique to each offspring's life history. It could be that some anatomical or physiological adjustments or alterations crucial to survival in the cold marine environment are governing how and where various FAs should be deposited in this early phase of life. Thus, the lactation situation may not be completely representative of the way dietary FAs are deposited during fattening events later in life.

Acknowledgements. We thank O. Dove, I. Gjertz, H. Lund and T. Martin for help in the field. This study was supported by funds from the Norwegian Polar Institute and the University Courses in Svalbard (UNIS).

\section{LITERATURE CITED}

Ackman RG, Eaton CA, Jangaard PM (1965) Lipids from the fin whale (Balaenoptera physalus) from North Atlantic waters. I. Fatty acid composition of whole blubber and blubber sections. Can J Biochem 43:1513-1520

Ackman RG, Hingley J, Eaton CA, Sipos JC, Mitchell ED (1975) Blubber fat deposition in mysticeti whales. Can J Zool 53:1332-1339

Bradshaw CJA, Hindell MA, Best NJ, Phillips KL, Wilson G, Nichols PD (2003) You are what you eat: describing the foraging ecology of southern elephant seals (Mirounga leonina) using blubber fatty acids. Proc R Soc Lond Ser B 270:1283-1292

Brodie PF (1971) A reconsideration of aspects of growth, reproduction, and behavior of the white whale (Delphinapterus leucas), with reference to the Cumberland Sound, Baffin Island, population. J Fish Res Board Can 28:1309-1318

Brodie PF (1989) The white whale Delphinapterus leucas (Pallas, 1776). In: Ridgway SH, Harrison R (eds) Handbook of marine mammals, Vol 4. River dolphins and larger toothed whales. Academic Press, London, p 119-144

Dahl TM, Lydersen C, Kovacs KM, Falk-Petersen S, Sargent J, Gjertz J, Gulliksen B (2000) Fatty acid composition of the blubber in white whales (Delphinapterus leucas). Polar Biol 23:401-409

Doidge DW (1990) Integumentary heat loss and blubber distribution in the beluga, Delphinapterus leucas, with comparisons to the narwhal, Monodon monoceros. Can Bull Fish Aquat Sci 224:129-140

Fredheim B, Holen S, Ugland KI, Grahl-Nielsen O (1995) Fatty acid composition in blubber, heart and brain from phocid seals. In: Blix AS, Walløe L, Ulltang $\varnothing$ (eds) Whales, seals, fish and man. Elsevier, Amsterdam, p 153-168

Grahl-Nielsen O, Barnung T (1985) Variation in the fatty acid profiles of marine animals caused by environmental and developmental changes. Mar Environ Res 17:218-222

Grahl-Nielsen O, Hammill MO, Lydersen C, Wahlstrøm S (2000) Transfer of fatty acids from female seal blubber via milk to pup blubber. J Comp Physiol B 170:277-283
Grahl-Nielsen O, Andersen M, Derocher AE, Lydersen C, Wiig Ø, Kovacs KM (2004) Reply comment: sampling, data treatment and predictions in investigations on fatty acids in marine mammals. Mar Ecol Prog Ser 281:303-306

Heide-Jørgensen MP, Teilmann J (1994) Growth, reproduction, age structure and feeding habits of white whales (Delphinapterus leucas) in West Greenland waters. Meddr Grønland Biosci 39:195-212

Hooker SK, Iverson SJ, Ostrom P, Smith SC (2001) Diet of northern bottlenose whales inferred from fatty-acid and stable-isotope analyses of biopsy samples. Can J Zool 79: $1442-1454$

Iverson SJ (1993) Milk secretion in marine mammals in relation to foraging: can milk fatty acids predict diet? Symp Zool Soc Lond 66:263-291

Iverson SJ, Oftedal OT, Bowen WD, Boness DJ, Sampugna J (1995a) Prenatal and postnatal transfer of fatty acids from mother to pup in the hooded seal. J Comp Physiol B 165: $1-12$

Iverson SJ, Hamosh M, Bowen WD (1995b) Lipoprotein lipase and its relationship to high milk fat transfer during lactation in grey seals. J Comp Physiol B 165:384-395

Iverson SJ, Frost KJ, Lowry LF (1997) Fatty acid signature reveal fine scale structure of foraging distribution of harbor seals and their prey in Prince William Sound, Alaska. Mar Ecol Prog Ser 151:255-271

Iverson SJ, Fields C, Bowen WD, Blanchard W (2004) Quantitative fatty acid signature analysis: a new tool of estimating predator diets. Ecol Monogr 74:211-235

Käkelä R, Hyvärinen H (1996) Site-specific fatty acid composition in adipose tissue of several northern aquatic and terrestrial mammals. Comp Biochem Physiol B 115: 501-514

Kirsch PE, Iverson SJ, Bowen WD (2000) Effect of a low-fat diet on body composition and blubber fatty acids of captive juvenile harp seals (Phoca groenlandica). Physiol Biochem Zool 73:45-59

Kouba M, Hermier D, Le Dividich J (1999) Influence of a high ambient temperature on stearoyl-CoA-desaturase activity in the growing pig. Comp Biochem Physiol B 124:7-13

Kvalheim OM, Karstang TV (1987) A general-purpose program for multivariate data analysis. Chemometr Intell Lab Syst 2:235-237

Lydersen C, Martin AR, Kovacs KM, Gjertz I (2001) Summer and autumn movements of white whales Delphinapterus leucas in Svalbard, Norway. Mar Ecol Prog Ser 219: 265-274

Ntambi JM (1999) Regulation of stearoyl-CoA desaturase by polyunsaturated fatty acids and cholesterol. J Lipid Res 40: 1549-1558

O'Corry-Crowe GM (2002) Beluga whale Delphinapterus leucas. In: Perrin WF, Würsig B, Thewissen JGM (eds) Encyclopedia of marine mammals. Academic Press, San Diego, CA, p 94-99

Olsen E, Grahl-Nielsen O (2003) Blubber fatty acids of minke whales: stratification, population identification and relation to diet. Mar Biol 142:13-24

Sergeant DE, Brodie PF (1969) Body size in white whales, Delphinapterus leucas. J Fish Res Board Can 26:2561-2580

St Aubin DJ, Smith TG, Geraci JR (1990) Seasonal epidermal moult in beluga whales, Delphinapterus leucas. Can J Zool 68:339-367

West GC, Burns JJ, Modafferi M (1979) Fatty acid composition of Pacific walrus skin and blubber fats. Can J Zool 57: $1249-1255$

Submitted: June 23, 2004; Accepted: January 4, 2005

Proofs received from author(s): May 25, 2005 